\title{
A preliminary study of printed electronics through flexography impression on flexible substrates
}

DOI: $10.35530 / I T .072 .02 .202024$

\begin{abstract}
REZUMAT
A preliminary study of printed electronics through flexography impression on flexible substrates

The work is framed within Printed Electronics, an emerging technology for the manufacture of electronic products. Among the different printing methods, the roll-to-roll flexography technique is used because it allows continuous manufacturing and high productivity at low cost. Apart from the process parameters, the ink and the substrate properties are some of the variables associated with the flexographic printing. Specifically, this study investigates the ink penetration, the print uniformity, the adhesion, the fastness, and the electrical behaviour of the same conductive silver ink printed on different flexible substrates through the flexography process. In addition to polymeric and siliconized paper substrates, which are typical used in printed electronics, two substrates were also chosen for the study: woven and nonwoven fabric. Optical, scanning electronic microscope (SEM), 4-point Kelvin and colour fastness to wash and rubbing analyses have been performed. The results concluded that, regarding the conductivity behaviour, porous substrates like textiles and nonwoven fabrics without pre and post treatments do not present acceptable results, whereas polymers or silicone papers do. Nevertheless, woven and nonwoven fabrics are a suitable early option regarding colour fastness to wash instead of thin polymeric and paper substrates that tear at the wash machine. A solution for an optimal printing on textiles would be the surface substrates pre-treatment by applying different chemical compounds that increase the adhesion of the ink on the fabric.
\end{abstract}

Keywords: smart textile, wearable, printed-electronics, conductivity, flexography

\section{Studiu preliminar privind electronicele imprimate prin flexografie pe suporturi flexibile}

Lucrarea este încadrată în domeniul electronicelor imprimate, o tehnologie emergentă pentru obținerea produselor electronice. Printre diferitele metode de imprimare, se folosește tehnica de flexografie directă, deoarece permite fabricarea continuă și productivitatea ridicată la un cost redus. În afară de parametrii procesului, cerneala și proprietățile substratului sunt câteva dintre variabilele asociate cu imprimarea flexografică. Mai exact, acest studiu investighează penetrarea cernelii, uniformitatea imprimării, aderența, rezistența culorii și comportamentul electric al aceleiași cerneli conductoare pe bază de argint imprimată pe diferite substraturi flexibile, prin procesul de flexografie. În plus față de substraturile de hârtie polimerice și siliconate, care sunt utilizate în mod tipic în electronica imprimată, au fost selectate pentru studiu două substraturi: materialele textile țesute și materialele textile nețesute. Au fost efectuate analize microscopice optice, cu scanare electronică (SEM), Kelvin în 4 puncte și rezistența culorii la spălare și frecare. Rezultatele au arătat că, în ceea ce privește comportamentul de conductivitate, substraturile poroase, cum ar fi materialele textile țesute și nețesute fără pre și post-tratament, nu prezintă rezultate acceptabile, în timp ce hârtia polimerică și cea siliconată prezintă rezultate bune. Cu toate acestea, materialele textile țesute și nețesute reprezintă o opțiune adecvată în ceea ce privește rezistența culorii la spălare, în locul substraturilor subțiri polimerice și de hârtie care au tendința de sfâșiere la mașina de spălat. O soluție pentru o imprimare optimă pe materiale textile ar fi pretratarea substraturilor de suprafață prin aplicarea diferiților compuși chimici, care cresc aderența cernelii pe materialul textil.

Cuvinte-cheie: textile inteligente, purtabile, electronice imprimate, conductivitate, flexografie

\section{INTRODUCTION}

The technology that allows the fabrication of electronic devices through a printing process is known as printed electronics (PE). It is one of the fastest growing technologies in the world as it provides different printing techniques for fabricating low-cost and largearea flexible electronic devices [1]. In recent years, the technology of flexible electronics has attracted considerable attention as it is applicable to wearable devices including flexible displays, flexible batteries and flexible sensors [2] in different areas such as aerospace and automotive, biomedical, robotics, and health applications [3]. Among them, wearable electronic textiles (e-textiles) are of great significance, as they provide better comfortability, durability and lighter weight as well as maintaining the desirable electrical property [4].

The PE printing technique selection shall be according to the type of electronic application (e.g., small, thin, lightweight, flexible, and disposable, etc.) to be fabricated, the production cost and volume. Also, the materials (inks/pastes and substrates) must meet certain requirements, depending on the type of printing technology being used and the final application. 
PE technologies are divided in contact techniques (e.g., flexography, gravure printing and soft lithography techniques), in which the printing plate is in direct contact with the substrate and, non-contact techniques (e.g., screen printing, aerosol printing, inkjet printing, laser direct writing), where only the inks get in contact with the substrate $[5,6]$. Those techniques suitable for roll-to-roll (R2R) processing, such as flexography, are especially attractive as they offer continuous production and high productivity [7].

Flexographic printing is known for depositing a wide range of thicknesses with the same resolution. Impression cylinder, plate cylinder, anilox roller, doctor blade and inking unit are the main parts of the flexographic printing [1]. Variables associated with the flexographic printing process include print speed, print force/engagement, anilox cell volume, anilox force/engagement as well as the ink and substrate properties. [8] Those variables have a direct impact on the prints' morphological and electrical behaviour, as well as the print uniformity has a considerable influence on the final functionality of the device [9]. It must be highlighted in the context of printed electronics on fabrics, the challenge of durability and withstanding bending, stretching, abrasion and washing [10].

Numerous reviews and books have been already published considering printed electronics on substrates that are usually used on electronic devices

\section{MATERIALS AND METHODS}

\section{Materials}

In addition to polymeric and siliconized paper substrates, which are typical used in printed electronics $[3,7]$, two substrates were also chosen for the study: woven and nonwoven fabric. The four flexible substrates are characterized in table 1.

Same aqueous flexo-printable conductive ink, PFI-600 - Silver ink from Novacentrix, has been used in all prints to ensure comparable results. The ink contains silver nanoparticles and has been formulated for high conductivity, fast curing, and improved levelling at lower printing speeds.

\section{Methods}

Flexography is a roll-to-roll direct printing technology, where an anilox roller, covered with micro-cavities on its surface, allows the collection of ink, and then is transferred to the printing plate cylinder. At the study, the one-layer flexography printing process has been performed using flexography experimental plants (Flexo VCML Lab from RK and Lambda from Edale) for printing the samples. Different test drawings for the pattern of the printing plate cylinder were designed specifically for the study. Details of the process are described in table 2.

Printed layers were dried using an in-line air flow convection dryer with temperatures within $80-150^{\circ} \mathrm{C}$.

Table 1

\begin{tabular}{|c|c|c|c|c|c|c|}
\hline \multicolumn{7}{|c|}{ SUBSTRATES CARACHTERIZATION } \\
\hline Code & Substrate & Material & Structure & $\begin{array}{c}\text { Mass per unit } \\
\text { area* }\end{array}$ & Color & Protector \\
\hline SA & Woven fabric & $100 \%$ Cotton & Plain & $300 \mathrm{~g} / \mathrm{m}^{2}$ & Greige & No \\
\hline SB & $\begin{array}{c}\text { Spunbonded } \\
\text { Nonwoven fabric }\end{array}$ & $100 \%$ Polypropylene & Nonwoven & $50 \mathrm{~g} / \mathrm{m}^{2}$ & White & No \\
\hline SC & Paper & Siliconized paper & - & $140 \mathrm{~g} / \mathrm{m}^{2}$ & White & No \\
\hline SD & Polymeric & $\begin{array}{c}100 \% \text { Thermoplastic } \\
\text { Polyurethane }\end{array}$ & - & $94 \mathrm{gr} / \mathrm{m}^{2}$ & Transparent & $\begin{array}{c}\text { Yes } \\
\text { (white paper) }\end{array}$ \\
\hline
\end{tabular}

Note: * Mass per unit area determined according to the standard ISO 3801

such as glass, metal, paper or polymers [3, 7]. However, the incorporation of the flexography printing technique for printed electronics in the textile field is still very recent and there are not enough studies for its application. As a result, the authors have proposed to analyse this printing methodology for conductive inks on textiles regarding their electronic performance.

In order to compare the results of the impression carried out on different laminar substrates, printed samples were characterized using the optimal microscope and the scanning electron microscope (SEM). The behaviour of the impression is evaluated before maintenance actions such as washing and rubbing.
Table 2

\begin{tabular}{|c|c|c|c|}
\hline \multicolumn{4}{|c|}{ PRINTING PROCESS VARIABLES } \\
\hline Code & Ink & $\begin{array}{c}\text { Anilox volume } \\
\left(\mathbf{c m}^{\mathbf{3}} / \mathbf{m}^{\mathbf{2}}\right)\end{array}$ & $\begin{array}{c}\text { Print speed } \\
\text { (m/min) }\end{array}$ \\
\hline SA & PFI-600 & 12 & $6-22$ \\
\hline SB & PFI-600 & 12 & $6-22$ \\
\hline SC & PFI-600 & 11 & 5 \\
\hline SD & PFI-600 & 12 & $6-22$ \\
\hline
\end{tabular}

\section{RESULTS AND DISCUSSSION}

\section{Ink uniformity}

The optical macroscopic images were taken with a LEICA MZ APO stereomicroscope. It was used to analyse the print uniformity of each layer of the electronic 
printed samples. Magnifications from 20 to 80 were used. Table 3 shows images of the $20 \times$ results.

It is observed that both woven and non-woven fabric do not present uniformity at the print, due to the porous surface. Printing electronics with low viscosity inks onto a rough and porous textile surface is of great challenge, due to the orientation of fibres or yarns and the change of fibre morphology constantly [4].

\section{Ink penetration}

High-resolution topographic images by SE (secondary electrons) and maps of crystalline and textural orientations by EBSD (electron backscatter diffraction) were taken with a ZEISS ULTRA 55 Scanning Electron Microscope Field Emission Gun (field emission scanning electron microscopy (FESEM)). They were used to analyse the ink penetration

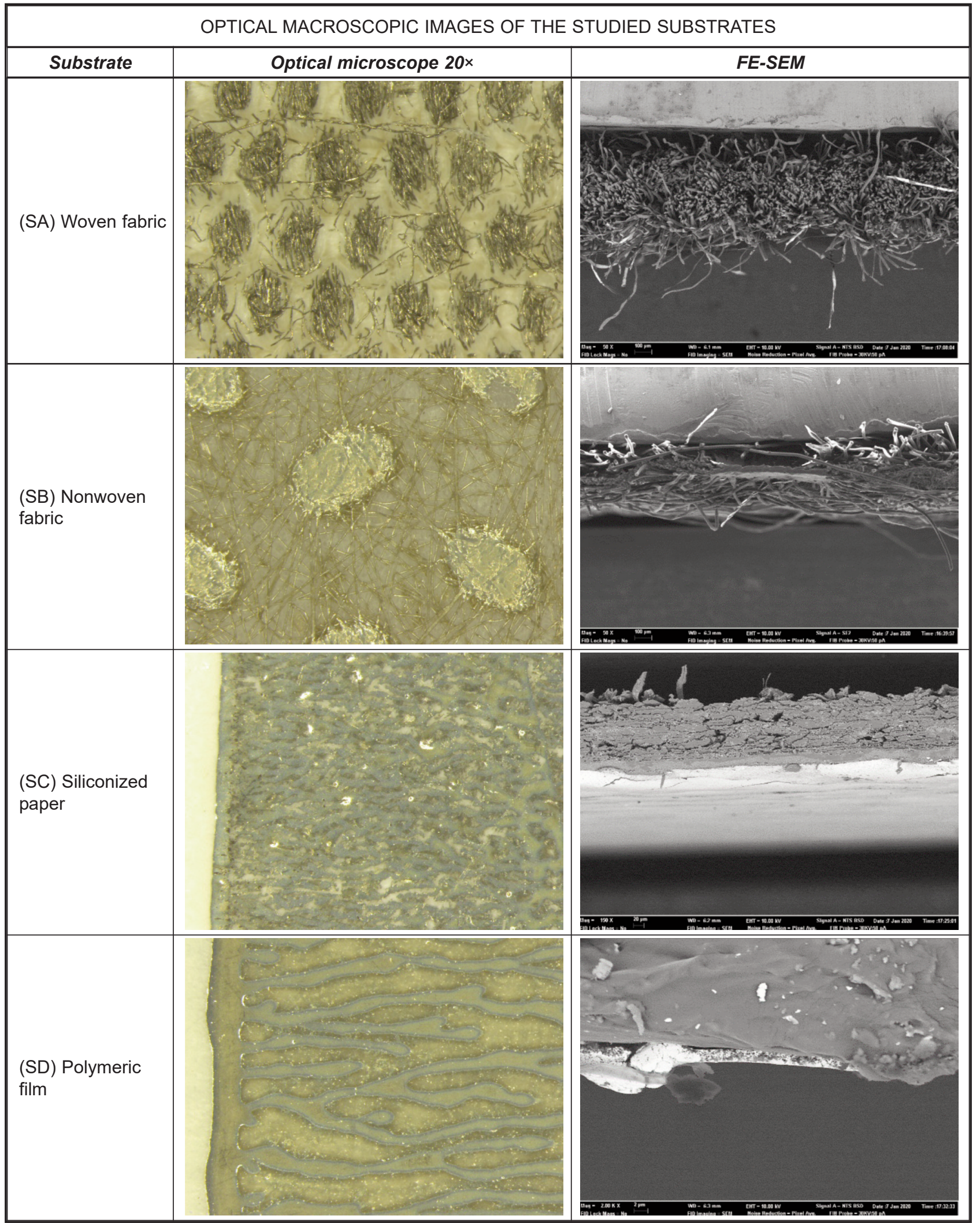


and the adhesion in each substrate. Table 3 shows the FE-SEM images obtained.

These images confirm that the continuity of the ink does not appear on the woven and non-woven fabrics, being able to observe a space between the ink and the surface of the fabric, not being completely adhered to the substrate. This does not observed when the ink is deposited on the paper, as it is much more uniform, the ink is completely in contact with the surface.

\section{Conductivity}

To measure the electrical behaviour a usual two-terminal sensing unit was firstly considered.

Nevertheless, a two-wire system does not provide correct output due to variation in ambient temperature, as the resistance of the lead wires (both sides) changes unpredictably. Meanwhile, Four-Wire Kelvin resistance measurement makes it possible to accurately measure resistance values less than $0.1 \Omega$ while eliminating the inherent resistance of the lead wires connecting the measurement instrument to the component being measured [11]. For that reason, 4-wire system measurements were made Resistance measurements were made with a FLUKE 8845A multimeter from FLUKE CORPORATION (Everett, Washington, USA). Table 4 shows the results obtained for each substrate.

Table 4

\begin{tabular}{|c|c|c|}
\hline \multicolumn{3}{|c|}{ KELVIN (4-WIRE) RESISTANCE MEASUREMENT } \\
\hline Code & Substrate & Resistance $(\Omega)$ \\
\hline SA & Woven fabric & - \\
\hline SB & Spunbonded nonwoven fabric & - \\
\hline SC & Paper & 1.2450 \\
\hline SD & Polymeric & 1.9747 \\
\hline
\end{tabular}

Whereas the results for paper and polymeric substrates indicate that the printing is conductive, neither the woven nor the nonwoven fabrics present electrical conductivity. This is because poor uniformity limits the conductivity of a print, leading to functional variation and short circuits. In order to address these challenges, surface pre-treatment onto rough and porous substrates or coating and lamination processes should be done in order to produce continuous conductive pathway onto textiles $[4,6]$.

\section{Colour fastness}

The grade of colour fastness to wash and rubbing of the electronic flexo printed samples were evaluated and presented in the table 5 . Neither the siliconized paper (SC) nor the polymeric substrate (SD) could stand the washing test and were torn at the wash machine. Furthermore, the SD was not capable of withstanding the rubbing test, crashing with the pressure of the crockmeter.

The overall results of colour fastness to rubbing of samples showed poor fastness properties in terms of discharge, which was harmonious with previous studies of other printing techniques [12]. SA and SB showed an improved grade in the rubbing degradation possibly due to the large amount of ink deposited on the surface although wet rubbing properties are lower than dry. In order to address these challenges, surface pre-treatment onto rough and porous substrates should be done in order to improve the ink adhesion and therefore the electrical behaviour [4]. On the other hand, the overall results of colour fastness to wash of woven (SA) and nonwoven (SB) fabrics samples were very good to excellent. According to a previous review [13], an increment of ink volume improves the ink coverage, upgrading in this case the conductivity, nevertheless it enhances the ink washout effect. For this reason, the ink volume transferred to the substrate should be optimized when conductivity and colour fastness to washing are the objectives. In addition, coating and lamination processes could be done in order to ensure the continuous conductive pathway on textiles [10].

\section{CONCLUSIONS}

By a comparison of the same ink printed on different flexible substrates it has been concluded that the rollto-roll flexography printing process is an effective technique to produce conductive tracks on silicone paper and polymer flexible substrates. Nevertheless, it has been demonstrated that the same silver ink printings do not present uniformity, ink penetration and electrical conductivity onto textile and non-woven fabrics. For this reason, future work will explore different surface pre-treatments, such as hydrophobic and oleophobic treatments, in order to improve ink uniformity and then produce continuous conductive pathway through flexography on textiles and nonwoven fabrics.

\begin{tabular}{|c|c|c|c|c|c|c|}
\hline \multicolumn{7}{|c|}{ COLOR FASTNESS TO WAS AND RUBBING RESULTS } \\
\hline \multirow{3}{*}{ Code } & \multicolumn{4}{|c|}{ Rubbing } & \multicolumn{2}{|c|}{ Washing } \\
\hline & \multicolumn{2}{|c|}{ Degradation } & \multicolumn{2}{|c|}{ Discharge } & \multirow{2}{*}{ Degradation } & \multirow{2}{*}{ Discharge } \\
\hline & Dry & Wet & Dry & Wet & & \\
\hline SA & $4-5$ & $3-4$ & 1 & 1 & 4 & 5 \\
\hline SB & 4 & $1-2$ & 3 & 2 & 4 & 5 \\
\hline SC & 2 & 1 & 3 & 1 & - & - \\
\hline SD & - & - & - & - & - & - \\
\hline
\end{tabular}


On the other hand, woven and nonwoven fabrics are a suitable early option regarding colour fastness to wash instead of thin polymeric and paper substrates that tear at the wash machine. The ink volume transferred to the substrate should be optimized when conductivity and colour fastness to washing are the objectives. Future work will also explore several coatings that could also be applied after the printing to protect the circuits and then improve the electronic behaviour after washing. Concerning colour fastness to rubbing, even better than for thin polymeric and paper substrates, poor results were obtained for woven and nonwoven fabrics. For this reason, future work will be focused on surface pre-treatment onto rough and porous substrates in order to improve the ink adhesion and therefore the electrical behaviour.

\section{ACKNOWLEDGEMENTS}

This research is part of HYBRID project that is funded by the Conselleria d'Economia Sostenible, Sectors Productius i Treball, through IVACE. Application No.: IMAMCI/2020/1.

\title{
REFERENCES
}

[1] Avuthu, S.G., Gill, M., Ghalib, N., Sussman, M.R., Wable, G., Richstein, J.Ph., Jabil, D., An introduction to the process of printed electronics, 2016

[2] Kim, C., Jeon, S., Kim, C.-H., Reduction of Linearly Varying Term of Register Errors Using a Dancer System in Rollto-Roll Printing Equipment for Printed Electronics, In: International Journal of Precision Engineering and Manufacturing, 2019, https://doi.org/20.10.1007/s12541-019-00157-2

[3] Cruz, S., Rocha, L., Viana, J., Printing Technologies on Flexible Substrates for Printed Electronics, 2018, https://doi.org/10.5772/intechopen.76161

[4] Karim, N., Afroj, S., Novoselov, K., Yeates, S., All Inkjet-Printed Graphene-Silver Composite Ink on Textiles for Highly Conductive Wearable Electronics Applications, In: Scientific Reports, 2019, 8035, 1-10, https://doi.org/10.1038/s41598-019-44420-y

[5] Cano-Raya, C., Denchev, Z., Cruz, S., Viana, J., Chemistry of solid metal-based inks and pastes for printed electronics - A review, In: Applied Materials Today, 2019, 15, 416-430, https://doi.org/10.1016j.apmt.2019.02.012

[6] Yang, K., Torah, R., Wei, Y., Beeby, S., Tudor, J., Waterproof and durable screen printed silver conductive tracks on textiles, In: Textile Research Journal, 2013, 83, 2023-2031, https://doi.org/10.1177/0040517513490063

[7] Søndergaard, R., Hosel, M., Krebs, F., Roll to roll fabrication of large area functional organic materials, In: Journal of Polymer Science, 2012, 51, 16-34

[8] Mogg, B., Claypole, T., Deganello, D., Phillips, C.O., Flexographic printing of ultra-thin semiconductor polymer layers, In: Translational Materials Research, 2016, 3, 015001, https://doi.org/10.1088/2053-1613/3/1/015001

[9] Davide, D., Control of morphological and electrical properties of flexographic printed electronics through tailored ink rheology, In: Organic Electronics, 2019, 73, 212-218

[10] Yang, K., Torah, R., Wei, Y., Beeby, S., Tudor, J. Waterproof and durable screen printed silver conductive tracks on textiles, In: Textile Research Journal, 2013, 83, 19, 2023-2031

[11] Revuelta, P., Litrán, S., Thomas, J., Electrical Power Terms in the IEEE Std 1459 Framework, 2016, https://doi.org/10.1016/B978-0-12-803216-9.00002-X

[12] Vasić, J., Kasikovic, N., Delic, G., Đurđević, M., Impact of type of ink and substrate on colorimetric values of inkjet prints, 2018, 365-372, https://doi.org/10.24867/GRID-2018-p44

[13] Kasikovic, N., Vladić, G., Milic, N., Novaković, D., Milošević, R., Dedijer, S., Colour fastness to washing of multilayered digital prints on textile materials, In: Journal of the National Science Foundation of Sri Lanka, 2018, 46, 381, https://doi.org/10.4038/jnsfsr.v46i3.8489

\author{
Authors: \\ ANA M. RODES-CARBONELL ${ }^{1}$, JOSUÉ FERRI ${ }^{1}$, EDUARDO GARCIA-BREIJO², \\ EVA BOU-BELDA ${ }^{3}$ \\ ${ }^{1}$ Textile Research Institute (AITEX), Alcoy 03801, Spain \\ ${ }^{2}$ Instituto Interuniversitario de Investigación de Reconocimiento Molecular y Desarrollo Tecnológico (IDM), \\ Universitat Politècnica de València, Valencia 46022, Spain \\ e-mail: egarciab@eln.upv.es \\ ${ }^{3}$ Department of Textile and Paper Engineering, Universitat Politècnica de València, \\ Plaza Ferrándiz y Carbonell s/n. 03801, Alcoy, Spain \\ e-mail: evbobel@upvnet.upv.es
}

\section{Corresponding author:}

ANA M. RODES-CARBONELL

e-mail: arodes@aitex.es 